
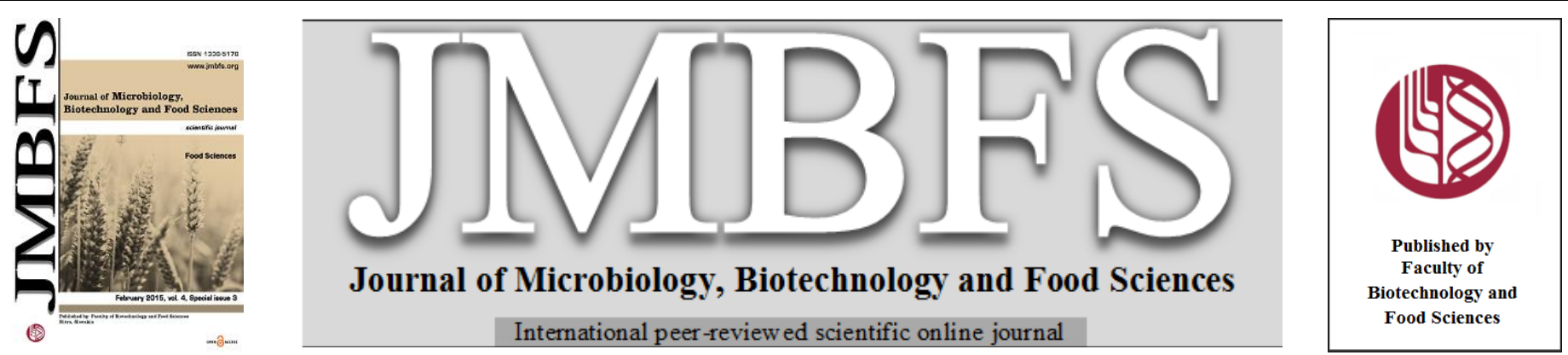

\title{
THE EFFECT OF TEMPERATURE DURING TRANSPORTATION TO THE QUALITY OF PORK
}

\section{Juraj Mlynek ${ }^{* 1}$, Ivan Imrich ${ }^{2}$, Eva Mlyneková ${ }^{1}$}

Address(es): prof. Ing. Juraj Mlynek, CSc.

${ }^{1}$ Slovak University of Agriculture, Faculty of Agrobiology and Food Resources, Department of Animal Husbandry, Tr. A. Hlinku 2, 94976 Nitra, Slovak Republic, phone number: +421 376414410 .

${ }^{2}$ Slovak University of Agriculture, Faculty of Agrobiology and Food Resources, Department of Veterinary Sciences, Tr. A. Hlinku 2, 94976 Nitra, Slovak Republic.

*Corresponding author: juraj.mlynek@uniag.sk

doi: $10.15414 /$ jmbfs.2015.4.special3.122-124

\section{ART ICLE INFO}

Received 28.11.2014

Revised 4. 12. 2014

Accepted 5. 12. 2014

Published 2. 2. 2015

Regular article open 2 access

\begin{abstract}
The aim of the experiment was to assess the impact of different temperature during transportation on the pork quality. Two th ousand eleven commercial pigs hybrids, weighing 100-130 kg were used in the experiment. Acidity of meat and muscle temperature were assessed 45 minutes after slaughter in the longest back muscles between the next to last and last thoracic vertebrae (musculus longissimus dorsi, pars thoracis) - $\mathrm{pH}_{1} \mathrm{MLD}$ and T MLD, and in the geometric center semimembranosus thigh muscle (musculus semimembranosus) - $\mathrm{pH}_{1} \mathrm{MSM}$ and T MLD. Pigs were divided into groups according to the temperature during housing in slaughterhouse using quartile distribution. Experiment results show that increase of average daily temperat ure during the transport resulted in worse quality of meat in MLD which was shown in $\mathrm{pH}_{1}$ MLD decrease and the temperature MLD increase. More significant $\mathrm{pH}_{1}$ (5.97) decrease occurred during average daily temperature higher than $15.0^{\circ} \mathrm{C}$ and at this temperature the most significant temperature increase occurred in MLD muscle. Also the $\mathrm{pH}_{1}$ MSM indicator showed decrease in average values due to average outer temperature increase. The lowest $\mathrm{pH}_{1} \mathrm{MSM}$ (6.22) value was detected in the group with average daily temperat ure during transport above $15{ }^{\circ} \mathrm{C}$. Lower $\mathrm{pH}_{1}$ values were detected in musculus longissimus dorsi.
\end{abstract}

Keywords: Acidity of meat, pork, temperature, transport

\section{INTRODUCTION}

The total meat consumption in the world in continuously rising and in global average approaches $42 \mathrm{~kg}$ per person annually. Pork meat dominates in consumption which represents $38-40 \%$ of the total market (Pažout 2010). At the present, the number of consuments is growing, those who look for quality articles of food (Václavk ová and Lustiková, 2010). For the consumers as well as for the meat industry, it is very important that the pork will be in good quality (Šprysl et $\boldsymbol{a l . , 2 0 1 0}$ ). The quality of pork is the result of a production system, such as the combination of genetic, rearing condition (Hluchý and Eliáš, 2006; Hluchý et al., 2007), age and weight at slaughter, handling, stress (Majorano et al., 2012), health (Rolinec et al., 2010; Kanka et al., 2014), as well as cooking method (Sinha et al.,2009). Transportation conditions such as ambient temperature, humidity, noise, loading and unloading, fighting due to the mixing of unfamiliar pigs and stocking too many animals in a truck mean severe stress for the animal resulting in an accelerated post-mortem glycolysis and impaired meat quality (Smulders and Van Laack, 1991; Andersen et al., 2005). The reaction organism to stress triggers increased glycolysis which occurs mainly after slaughter, which results in fast production of lactacid at high temperature immediately after slaughter. The result is meat which is significantly pale and exudative (Martinez-Rodriguez et al., 2011). From the view point of meat quality, the greatest problem is occurrence of PSE defect (Václavková and Lustikova, 2010). Pulkrábek et al. (2003) claim that pork quality detection is fairly complicated and that this is the reason why it is often deduced in the common practice based on the $\mathrm{pH}_{1}$ values. During inappropriate weather conditions (high air humidity and high temperature) it is necessary to secure the optimal conditions in inner truck spaces used for pig transport (Gade $\boldsymbol{e t}$ al., 2007). The aim of the experiment was to assess the impact of different temperature during transportation on the pork quality.

\section{MATERIAL AND METHODS}

Two thousand eleven commercial pigs hybrids, weighing 100-130 kg were used in the experiment. Influence of the average external temperature on the pork quality was evaluated during transport. Pigs were divided into four groups according to the average daily outer temperature during pigs transport to slaughterhouse using quartile distribution. Based on this distribution, the following groups were created: $\mathrm{S} 1$ with value up to $1.6{ }^{\circ} \mathrm{C} ; \mathrm{S} 2$ with value above 1.6 up to $9.9^{\circ} \mathrm{C} ; \mathrm{S} 3$ with value above 9.9 up to $15^{\circ} \mathrm{C}$ and group $\mathrm{S} 4$ above 15.0 ${ }^{\circ} \mathrm{C}$. Acidity and temperature of meat was assessed 45 minutes after slaughter in the longissimus muscle between the next to last and last thoracic vertebrae (musculus longissimus dorsi, pars thoracis) - $\mathrm{pH}_{1}$ MLD and T MLD in ${ }^{\circ} \mathrm{C}$, and in the geometric center semimembranosus thigh muscle (musculus semimembranosus) $-\mathrm{pH}_{1} \mathrm{MSM}$ and $\mathrm{T} \mathrm{MSM}$ in ${ }^{\circ} \mathrm{C}$. The right side of the carcass was used to perform meat quality measurements. Muscle $\mathrm{pH}$ and muscle temperature post mortem were measured using a portable apparat us TIT AN x.

\section{Statistical Analysis}

The results were processed in the SPSS 11.0 program. Following variables statistical values were calculated: minimum, maximum, arithmetic mean, standard deviation - S.D., variation coefficient in \% - VC \%. Differences between groups were tested using analy sis of variance with contrast testing using Tukey HSD test.

\section{RESULTS AND DISCUSSION}

Table 1 shows comparison of variation-statistical $\mathrm{pH}_{1}$ MLD values in relation to average daily temperature during pigs transport to slaughterhouse. Significantly the highest mean $\mathrm{pH}_{1} \mathrm{MLD}(\mathrm{P}<0.01)$ value was in pig groups transported during average daily temperatures up to $9.9^{\circ} \mathrm{C}$ (groups $\mathrm{S} 1$ and $\mathrm{S} 2$ ). With the increase of average daily temperature the $\mathrm{pH}_{1}$ MLD values decreased. Significantly the lowest $\mathrm{pH}_{1}$ MLD value $(\mathrm{P}<0.01)$ was detected in group $\mathrm{S} 4$ (5.97). The significance of results in muscle MLD temperature (Tab. 2) was detected at the $\mathrm{P}<0.01$ level between groups S1 and S4, S2 and S3, S2 and S4, S3 and S4 and at the level $\mathrm{P}<0.05$ between groups $\mathrm{S} 1$ and $\mathrm{S} 2$. Variability at this indicator was from 9.12 to $11.72 \%$. Based on these data we can state that with the increase of average daily temperature during transport, the meat quality worsened in MLD, which was expressed in significant $\mathrm{pH}_{1}$ in $\mathrm{MLD}$ decrease and by temperature rise in MLD. The most significant $\mathrm{pH}_{1}$ decrease occurred at average daily temperature higher than $15.0{ }^{\circ} \mathrm{C}$ and at this temperature occurred the most significant increase in muscle MLD temperature. Apart from listed results, 
Brandt et al. (2013) found higher mean $\mathrm{pH}_{1}$ values in musculus longissimus dorsi. $\mathrm{pH}_{1}$ values were at the level6.7 up to 6.8. Pigs came from four commercial hog breeding farms and were transported at average daily temperat ure in a truck at $14.8 \pm 1.8{ }^{\circ} \mathrm{C}$

Table 1 Comparison of variation-statistical $\mathrm{pH}_{1}$ MLD values in relation to average outer temperat ure during pigs transport

\begin{tabular}{ccccccc}
\hline group & n & minimum & maximum & mean & S.D. & CV \% \\
\hline S1 & 546 & 5.4 & 6.8 & 6.16 & 0.30 & 0.29 \\
S2 & 464 & 5.4 & 6.9 & 6.16 & 4.77 \\
S3 & 565 & 5.4 & 6.7 & 6.10 & 0.27 \\
S4 & 436 & 5.4 & 6.7 & 5.97 & 0.24 \\
\hline
\end{tabular}

Table 2 Comparison of variation-statistical values T MLD in relation to outer average temperature during pigs transport

\begin{tabular}{ccccccc}
\hline group & n & minimum & maximum & mean & S.D. \\
\hline S1 & 546 & 17.6 & 32.3 & 26.24 & 2.66 & 3.02 \\
S2 & 464 & 15.4 & 32.7 & 25.77 & 10.12 & 11.72 \\
S3 & 565 & 17.8 & 33.0 & 26.54 & 9.73 \\
S4 & 436 & 20.2 & 33.2 & 27.82 & 2.58 \\
\hline Legend: Statistically significant differences - S1:S2 (P<0.05); S1:S4 (P<0.01); S2:S3 (P<0.01); S2:S4 (P<0.01); S3:S4 (P<0.01)
\end{tabular}

Also in $\mathrm{pH}_{1}$ MSM indicator(Tab. 3) was detected decline in average values by the effect of rising average daily temperature. The lowest $\mathrm{pH}_{1} \mathrm{MSM}$ value (6.22) was detected in S4 group with average daily temperature during transport over 15 ${ }^{\circ} \mathrm{C}$. Statistically significant differences in $\mathrm{pH}_{1} \mathrm{MSM}$ were confirmed between groups $\mathrm{S} 3$ and $\mathrm{S} 4(\mathrm{P}<0.01)$ and groups $\mathrm{S} 1$ and $\mathrm{S} 3, \mathrm{~S} 2$ and $\mathrm{S} 3(\mathrm{P}<0.05)$. In table 4 are listed variation-statistical T MSM values. The lowest MSM temperature
(26.13) was in group of pigs transported at average daily temperatures from 1.6 to $9.9^{\circ} \mathrm{C}(\mathrm{S} 2)$. The highest MSM temperature was detected in group S4 (average daily temperatures over $15^{\circ} \mathrm{C}$ ). Statistically significant differences in MSM temperature were at the level $\mathrm{P}<0.01$ between groups $\mathrm{S} 1$ and $\mathrm{S} 2, \mathrm{~S} 1$ and $\mathrm{S} 4, \mathrm{~S} 2$ and $\mathrm{S} 3, \mathrm{~S} 2$ and $\mathrm{S} 4$ and also $\mathrm{S} 3$ and $\mathrm{S} 4$.

Table 3 Comparison of variation-statistical $\mathrm{pH}_{1} \mathrm{MSM}$ values in relation to average outer temperature during pigs transport

\begin{tabular}{|c|c|c|c|c|c|c|}
\hline group & $\mathbf{n}$ & minimum & maximum & mean & S.D. & CV \% \\
\hline S1 & 546 & 5.4 & 6.9 & 6.25 & 0.34 & 5.47 \\
\hline $\mathrm{S} 2$ & 464 & 5.4 & 6.9 & 6.25 & 0.34 & 5.40 \\
\hline S3 & 565 & 5.4 & 6.9 & 6.31 & 0.33 & 5.25 \\
\hline S4 & 436 & 5.4 & 6.9 & 6.22 & 0.30 & 4.85 \\
\hline
\end{tabular}

Table 4 Comparison of variation-statistical T MSM values in relation to outer average temperature during pigs transport

\begin{tabular}{ccccccc}
\hline group & n & minimum & maximum & mean & S.D. \\
\hline S1 & 546 & 17.9 & 31.3 & 26.77 & 2.55 & CV \% \\
S2 & 464 & 16.0 & 32.6 & 26.13 & 2.86 \\
S3 & 565 & 19.0 & 33.0 & 26.96 & 2.49 \\
S4 & 436 & 21.7 & 33.6 & 28.23 & 2.40 & 9.22 \\
\hline
\end{tabular}

Legend: Statistically significant differences: $\mathrm{S} 1$ :S2 (P<0.01), S1:S4 (P<0.01), S2:S3 (P<0.01) S2:S4 (P<0.01), S3:S4(P<0.01)

From the listed analyses of average daily outer temperatures during transport to slaught erhouse and $\mathrm{pH}_{1}$ MLD and MSM values is obvious that more significantly reacted to outer temperature muscle MLD than MSM. Muscle MLD and MSM temperature increased in both muscle groups in relation to outer temperature. In contrast to our results, Van de Perre et al. (2010) found significant higher $\mathrm{pH}_{1}$ in summer than in spring or autumn. As a result, a significant lower prevalence of PSE meat was found in summer. Gajana et al. (2013) did not report relationships between transportation time, distance, stocking density, temperature and lairage time and technological quality attributes ( $\mathrm{pH}$ ultimate) of pork. Kameník and Steinhauser (2012) list that PSE occurrence in meat is greater in summer than in winter because pigs do not have sweat glands in the skin and therefore they are more sensitive to higher temperatures which can act as stress factor. According to Václ avková and Lu styková (2010) transport during summer season increase the risk of PSE meat occurrence up to twofold. Similarly Guàrdia et al. (2004) stated that the PSE prevalence is expected to be higher in summer. Both high environmental temperatures in summer and temperature fluctuations affect the animal's ability to maintain body temperature which results in stress, a higher post-mortem muscle temperature and poorer meat quality (Guàrdia et al., 2004; Santos et al., 1997; W arriss, 1991). The ambient temperature at 7:00 a.m. in the summer months, especially in June, July and August during road transport is higher than $15^{\circ} \mathrm{C}$, thus negatively affecting the level of welfare and the number of pigs dying during transport to the slaughterhouse (Vecerek et al., 2006). These contentions are in accordance with our findings because growing average outer temperature statistically significantly affected the decline of $\mathrm{pH}_{1}$ values in MLD and increase of muscle MLD and MSM temperature.

\section{CONCLUSION}

Before the slaughter, various stressors affect the pork meat quality. Stressful can become also high temperature during transport. From the experiment result emerged that the most appropriate transport of pigs should occur at the temperature of less than $15^{\circ} \mathrm{C}$. During average daily temperature over $15^{\circ} \mathrm{C}$, the meat quality can worsen which will become evident by decrease of $\mathrm{pH}_{1} \mathrm{MLD}$ and MSM values and simultaneously by increase of temperature in mentioned muscles. Musculus longissimus reacted more sensitively to higher outer temperature of environment during transport.
Acknowledgments: this work has been created with the support of KEGA 006SPU-4/2014 and VEGA 1/0493/12.

\section{REFERENCES}

ANDERSEN, H.J., OKSBJERG, N., YOUNG, J.F., THERKILDSEN, M. 2005. Feeding and meat quality - a fut ure approach. Meat Science. 70(3), 543554.http://dx.doi.org/10.1016/j.meatsci.2004.07.015

BRANDT, P., ROUSING, T.,HERSKIN, M.S., AASLYNG, M.D. 2013.

Identification of post-mortem indicators of welfare of finishing pigs on the day of slaughter. Livestock Science 157(2-3), 535-544.

http://dx.doi.org/10.1016/j.livsci.2013.08.020

GUÀRDIA, M. D., EST ANY, J., BALASCH, S., OLIVER, M. A., GISPERT, M., DRIEST RE, A. 2004. Risk assessment of PSE condition due to pre-slaughter conditions and RYR1 gene in pigs. Meat Science, 67(3), 471-478. http://dx.doi.org/10.1016/j.meatsci.2003.11.020

GADE P.B. - CHRISTENSEN L. - BALTZER M. - PETERSEN J.V. 2007 Causes of pre-slaughter mortality in Danish slaughter pigs with special emphasis on transport. In Animal Welfare, 16(4), 459-470.

GAJANA, C.S., NKUKW ANA, T.T., MARUME, U., MUCHENJE, V. 2013.

Effects of transportation time, distance, st ocking density, temperature and lairage time on incidences of pale soft exudative (PSE) and the physico-chemical characteristics of pork. Meat Science, 95 (3), 520

525.http://dx.doi.org/10.1016/j.meatsci.2013.05.028

HLUCHÝ, S., ELIÁŠ, Z. 2006 Differences in musculus semimembranosus structure between pure breed and hybrid pigs. Scientifical Papers Animal Sciences and Biotechnologies, 39(1), 221-226.

HLUCHÝ, S., ELIÁŠ, Z., TOMAN, R. 2007 Histological structure of musculus longissimus dorsi in pigs with the same ryanodine receptor genotype (CC)in relation to feeding indicators. Scientifical Papers Animal Sciences and Biotechnologies, 40(1), 361-368.

KAMENÍK, J., STEINHAUSER, L. 2012. PSE, DFD and other meat quality defects. Maso, 23(6)., 57-61, ISSN 1210-4086.

KANKA, T., ROLINEC, M., BÍRO, D., ŠŤ AST NÝ.,P. 2014. Analýza pasívnej imunizácie prasiatok v postnatálnom období. SUA:Nitra, 164, ISBN 978-80-552$1181-7$.

MAJORANO, G., KAPELAŃSKY, W., BOCIAN, M., PIZZUTO, R., KAPELAŃSKA, J. 2012. Influence of rearing system, diet and gender on 
performance, carcass traits and meat quality of Polish Landrace pigs. Animal, 7(2), 341-347. http://dx.doi.org/10.1017/S1751731112001516

MARTINEZ-RODRIGUEZ, R., ROLDAN-SANTIAGO, P.,FLORESPEINADO, S., RAMIREZ-TELLES, J. A., MORA-MEDINA, P., TRUJILLOORTEGA, M. E., GONZALES-LOZANO, M., BECERRIL-HERRERA, M., SANCHEZ-HERNANDEZ, M., MOTA-ROJAS, D. 2011. Deterioration of pork quality due to the effects of acute ante mortem stress: An Overview. Asian Journal of Animal and Veterinary Advances, 6(12), 1170-1184. ISSN 1683-9919. http://dx.doi.org/10.3923/ajava.2011.1170.11784

PAŽOUT, V. 2010. Chov prasat a produkce vepřovéhov EU. Maso, 21(2), 4749, ISSN 1210-4086.

PULKRÁBEK, J., PAVLÍK, J., VALIŠ, L. 2003. Kvalita mäsa s ohl’adom na mäsnatost' ošípaných. Slovenský chov, 8(6), 26.

ROLINEC, M., BÍRO, D., ŠT̃ ASTNÝ, P., KANKA, T. 2010. Analyzis of haematological profile of piglets in early postnatal period. Acta fytotechnica et zootechnica, 13(special), 40-43.

SANTOS, C., ALMEIDA, J. M., MATIAS, E. C., FRAQUEZA, M. J., ROSEIRO, C., \& SARDINAH, L. 1997. Influence of lairage environmental conditions and resting time on meat quality in pigs. Meat Science, 45(2) 253-262. http://dx.doi.org/10.1016/S0309-1740(96)00048-4

SINHA, R., PARK, Y., GRAUBARD, B.I., LEITZMANN, M.F., HOLLENBECK, A., SCHATZKIN, A., CROSS, A.J. 2009. Meat and meat- related compounds and risk of prostate cancer in a large prospective cohort study in the United States. American Journal of Epidemiology, 170(9), 165-1177. http://dx.doi.org/10.1093\%2Faje\%2Fkwp280

SMULDERS, F. J. M., VAN LAACK, H. L. J. M. 1991. Pre-slaughter animal handling and fresh meat processing. Proceedings 37 th International Congres Meat Science Technology. Kulmbach, Germany, September 1-6.

ŠPRYSL, M., ČÍT EK, J., ST UPKA, R. 2010. Interaction of selected production indicators of the economics of pork production. Czech Journal of Animal Science, 55(1), 1-10

VÁCLAVKOVÁ, E., LUST YKOVÁ, A. 2010. Faktory ovlivňující kvalitu vepřového masa. Náś chov, 70(7), 32-33, ISSN 0027-8068.

VAN DE PERRE, V., PERMENTIER, L., DE BIE, S., VERBEKE, G., GEERS, R. 2010. Effect of unloading, lairage, pig handling, st unning and season on $\mathrm{pH}$ of pork. Meat science, 86(4), 931-937. http://dx.doi.org/10.1016/j.meatsci.2010.07.019

VECEREK, V., MALENA, M., MALENA JR., M., VOSLAROVA, E., CHLOUPEK, P. 2006. The impact of the transport distance and season on losses of fattened pigs during transport to the slaughterhouse in the Czech Republic in the period from 1997 to 2004. Veterinarni Medicina, 51(1), 21-28

WARRISS, P. D. 1991. A note on the influence of ambient temperature at slaughter on pig meat quality. Proceedings of the 37 th international congress of meat science and technology. Kulmbach, Germany, 301-304. 